\title{
Serum trypsin levels in acute pancreatic and non-pancreatic abdominal conditions
}

\author{
J. M. Gatell Artigas \\ M.D. \\ M. Elena Garcia \\ M.D. \\ M. R. Aused FAure \\ M.D. \\ A. M. Ballesta Gimeno
M.D. \\ Medical Clinic ' $B$ ' and Lab. of Clinical Biochemistry, Hospital Clinico, Faculty of Medicine, \\ Barcelona, Spain
}

\begin{abstract}
Summary
Serum trypsin levels have been estimated by radioimmunoassay in 26 healthy controls $(248 \pm 94.9 \mu \mathrm{g} / \mathrm{l}$; mean \pm s.d.), 12 patients with chronic renal failure $(1100 \pm 584 \mu \mathrm{g} / \mathrm{l}), 34$ with acute pancreatitis (1399 $\pm 618 \mu \mathrm{g} / \mathrm{l})$ and 23 with acute non-pancreatic abdominal conditions. Mean serum trypsin in acute pancreatitis and in chronic renal failure was significantly higher than in control group $(P<0 \cdot 001)$. Serum trypsin levels were well above the upper limit of normality in all patients with acute pancreatitis and in all but one with chronic renal failure. Serum trypsin was markedly raised in one patient with a traumatic haemoperitoneum and in one of the 11 with peptic ulcer perforation, and moderately raised in 3 of the 6 with acute cholecystitis.

Determination of serum trypsin seems to be a specific test for acute pancreatitis, provided renal failure has been excluded. However, the authors suggest it should be prospectively measured in a larger series of acute non-pancreatic abdominal conditions.
\end{abstract}

\section{Introduction}

Although increased circulating concentrations of amylase and lipase are very useful for the diagnosis of acute pancreatitis, they are not entirely specific (Banks, 1979; Lifton et al., 1974; Elias, Redshaw and Wood, 1977). In fact, it has been reported in many other acute non-pancreatic abdominal conditions such as peptic ulcer perforation, ileus or ischaemic bowel infarction (Banks, 1979; Warshaw and Lesser, 1975; Salt II and Shenker, 1976; Webster and Zieve, 1962a,b; Nardi, 1958).

Trypsin, unlike amylase and lipase, reflects only production by the pancreas (Elias et al., 1977) but

Correspondence: J. M. Gatell Artigas, M.D., Medical Clinic 'B', Hospital Clinico, Faculty of Medicine, Casanovas, 143, Barcelona-36, Spain. until recently was not as readily measurable (Elias et al., 1977; Temler and Felber, 1976). Since a specific, sensitive radioimmunoassay has been reported (Elias et al., 1977; Temler and Felber, 1976), raised immunoreactive serum trypsin has been found in a small series of acute pancreatitis, common duct gall-stones and chronic renal failure (Elias et al., 1977; Temler and Felber, 1976). In carcinoma of the pancreas immunoreactive serum trypsin may be normal or high (Elias et al., 1977) and normal or subnormal in chronic pancreatitis (Elias et al., 1977). As far as can be ascertained no other acute nonpancreatic abdominal conditions such as peptic ulcer perforation, acute cholecystitis, ileus or acute appendicitis have yet been tested by a radioimmunological method. Circulating trypsin has been estimated, however, in some isolated cases of acute non-pancreatic abdominal conditions, with variable results, by an enzymatic method.

The results of serum trypsin determination in a series of patients with chronic renal failure and acute pancreatic and non-pancreatic abdominal conditions are reported.

\section{Material and methods \\ Patients}

Serum trypsin was measured in 26 healthy controls and in 69 patients (See Table 1). Healthy controls were voluntary blood donors (Group I). Creatinine clearance was below $30 \mathrm{ml} / \mathrm{min}$ in all 12 patients with stable chronic renal failure (Group II). Group III was composed of 34 consecutive patients admitted with the diagnosis of acute pancreatitis. Serum amylase and lipase were above 1000 and 3 Coleman units/l respectively in all of them. Laparotomies were performed in 8 of them and a post-mortem in 4 . In all 23 patients (Group IV) with acute non-pancreatic abdominal conditions, the pancreas was grossly normal at laparotomy, serum amylase and lipase were 
TABLE 1. Data on groups in which serum trypsin was estimated

\begin{tabular}{|c|c|c|c|c|c|c|c|}
\hline Group & Diagnosis & & $\begin{array}{c}\text { Total } \\
\text { no. }\end{array}$ & $\begin{array}{c}\text { Mean age } \\
\text { (years) }\end{array}$ & $\begin{array}{c}\text { Age-range } \\
\text { (years) }\end{array}$ & $\begin{array}{c}\text { Males } \\
\text { no. }\end{array}$ & $\begin{array}{c}\text { Females } \\
\text { no. }\end{array}$ \\
\hline $\mathbf{I}$ & Healthy controls & & 26 & 35 & $20-52$ & 14 & 12 \\
\hline II & Chronic renal failure & & 12 & 62 & $45-72$ & 8 & 4 \\
\hline III & $\begin{array}{l}\text { Acute pancreatitis } \\
\text { Alcoholic } \\
\text { Biliary disease } \\
\text { Idiopathic } \\
\text { Recent surgery }\end{array}$ & $\begin{array}{r}(13) \\
(9) \\
(11) \\
(1)\end{array}$ & 34 & $51 \cdot 6$ & $32-75$ & 25 & 9 \\
\hline \multirow[t]{2}{*}{ IV } & \multirow{2}{*}{\multicolumn{2}{|c|}{$\begin{array}{l}\text { Acute non-pancreatic } \\
\text { abominal conditions } \\
\text { Peptic ulcer } \\
\text { perforation } \\
\text { Acute cholecystitis } \\
\text { Ileus } \\
\text { Acute appendicitis } \\
\text { Traumatic } \\
\text { haemoperitoneum } \\
\text { Choleperitoneum }\end{array}$}} & 23 & $55 \cdot 7$ & $20-67$ & 16 & 7 \\
\hline & & & $\overline{95}$ & & & $\overline{63}$ & $\overline{32}$ \\
\hline
\end{tabular}

normal, bile duct gall-stones were absent and renal function was normal, at least at the time of obtaining the blood sample.

\section{Serum samples and trypsin assay}

Serum trypsin estimations were performed in duplicate on one basal sample. Serum samples were obtained early after admission and before any medical or surgical treatment was started. Serum was stored at $-20^{\circ} \mathrm{C}$ for not more than 5 months.

Serum immunoreactive trypsin was estimated by means of one classic double-antibody radioimmunoassay (Ria-Gnost ${ }^{\circledast}$ Trypsine. Behring Institut). The directions of the kit were carefully and precisely followed. In the authors' laboratory the withinassay and the between-assay variance was $6.2 \%$ and $8.2 \%$ respectively. The lower and upper limits of detection were 18.7 and $1050 \mu \mathrm{g} / \mathrm{l}$. The assay was most precise between $75-550 \mu \mathrm{g} / \mathrm{l}$. Expected normal values ranged between $140-400 \mu \mathrm{g} / \mathrm{l}$.

\section{Statistical methods}

Groups were compared using the Student- $t$ test. A statistical significant difference was admitted if $P$ was less than 0.05 .

\section{Results}

The distribution of serum trypsin concentrations in healthy controls and in various conditions is shown in Fig. 1. Mean serum trypsin ( \pm s.d.) in healthy controls was $248 \pm 94.9 \mu \mathrm{g} / \mathrm{l}$ (range 58.2$437.8 \mu \mathrm{g} / 1$; mean \pm 2 s.d.). Mean serum trypsin in acute pancreatitis $(1399 \pm 618 \mu \mathrm{g} / \mathrm{l}$; mean \pm s.d. $)$ and in chronic renal failure $\left(1100 \pm 584 \mu \mathrm{g} / \mathrm{l}\right.$; mean \pm s.d. $\stackrel{\frac{7}{0}}{2}$ was significantly higher than in the control group. $(P<0.001)$. Serum trypsin levels were above ghछ upper limit of the normality in all patients with acite pancreatitis and in all but one with chronic reaf failure. Serum trypsin was markedly raised in ợe patient with a traumatic haemoperitoneum, and itक one of the 11 with peptic ulcer perforation, and moderately raised in 3 of the 6 with acute cholecy足 stitis (see Fig. 1).

\section{Discussion}

The radioimmunoassay of trypsin measures it immunological concentration and not its enzymatic biological activity (Elias et al., 1977; Temler an $\Phi$. Felber, 1976; Borgstrom and Ohlsson, 1978; Lakej Bakaar et al., 1980a). The radioimmunoassay of trypsin seems to be specific for trypsin and it $\$$ pro-enzyme trypsinogen, and not to be affected by the presence of circulating trypsin inhibitors (Elias et al., 1977; Temler and Felber, 1976). These in hibitors such as $\alpha_{1}$-antitrypsin and $\alpha_{2}$-macroglobulin make the measurement of trypsin as enzymatic activity difficult (Elias et al., 1977; Temler and Felber, ${ }^{\text {o }}$ 1976). Radioimmunoassay has been successfully applied to determine trypsin in serum, urine and duodenal fluid (Elias et al., 1977; Temler and Felberp 1976; Lake-Bakaar, McKavanagh and Summerfielde 1979; Lake-Bakaar et al., 1980a).

Serum trypsin has been reported to be constantly! raised in acute pancreatitis (Elias et al., 1977). Theo authors' results in a relatively large unselected series.

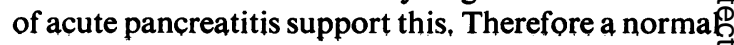




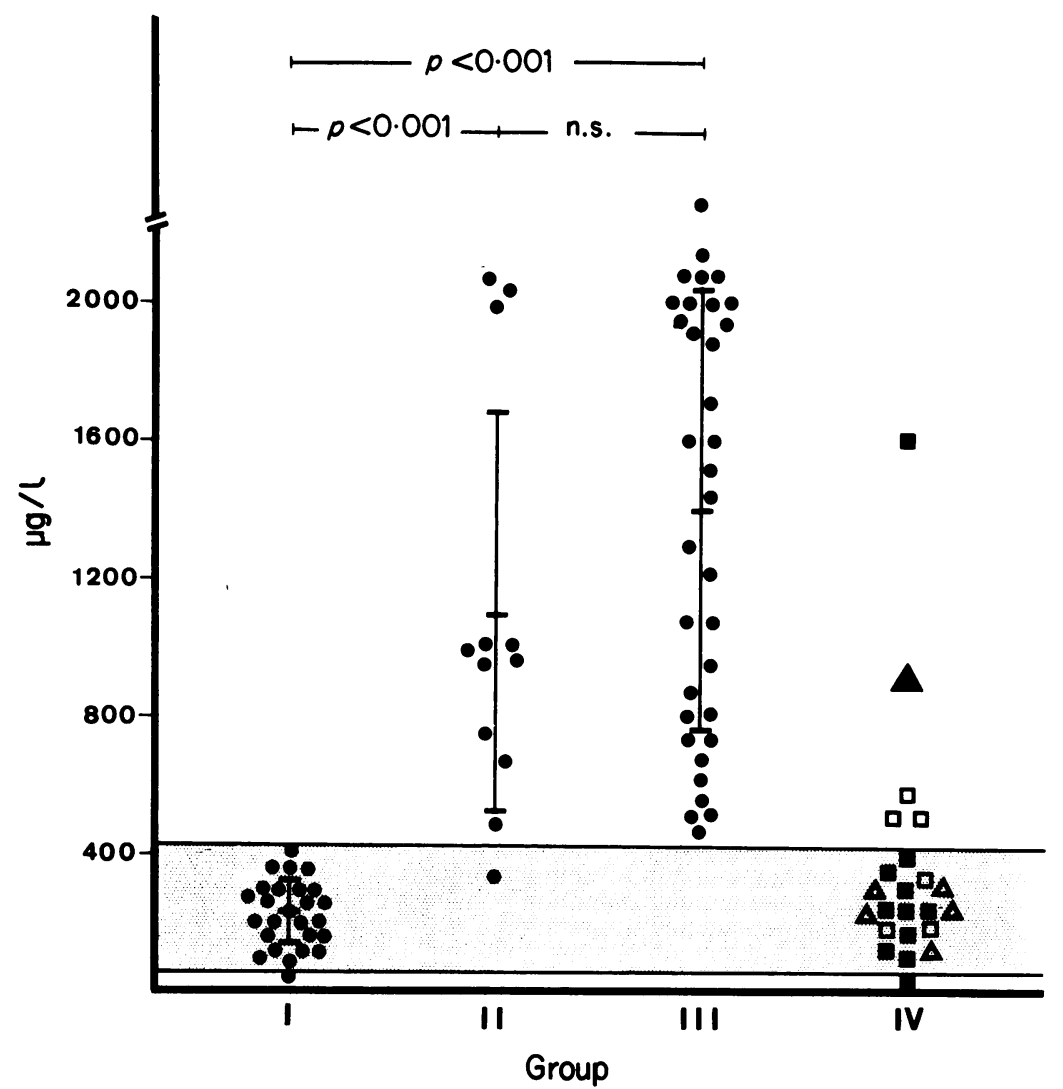

FIG. 1. Serum trypsin concentrations (mean \pm s.d.). $\square$, Peptic ulcer perforation; $\square$, cholecystitis; $\Delta$, haemoperitoneum; $\triangle$, others.

serum trypsin measurement might be very valuable to exclude acute pancreatitis in patients with increased serum amylase and lipase of non-pancreatic origin (Elias et al., 1977). Other conditions such as carcinoma of the pancreas and common duct gallstones can also occur with increased serum trypsin levels (Elias et al., 1977). Hypertrypsinaemia has been found in one and 2 patients with carcinomatosis and acute alcoholic hepatitis (Lake-Bakaar et al. 1978a). A rapid increase in serum trypsin has also been reported after endoscopic retrograde cholangiopancreatographic examination (Borgstrom and Ohlsson, 1978) although an acute pancreatitis is an uncommon complication (Borgstrom and Ohlsson, 1978; Banks, 1979; Zimmons et al., 1975).

For the diagnosis of acute pancreatitis trypsin has the advantage over $\alpha$-amylase and lipase in that it reflects only production by the pancreas (Elias et al., 1977). However, the way by which trypsin and other pancreatic enzymes reach the circulation, is not completely known (Elias et al., 1977). The venous, lymphatic and peritoneal absorption routes have been mentioned (Temler and Felber, 1976; Webster and Zieve, 1962a, b). An enteropancreatic circulation has been suggested for amylase and chymotrypsinogen (Liebow and Rothman, 1975), and convincingly demonstrated for trypsin (Lake-Bakaar et al., 1978b; Lake-Bakaar, Smith-Laing and Summerfield, 1978c; Lake-Bakaar et al., 1980b). A leakage of intraluminal contents, and peritoneal reabsorption might be the explanation of the raised serum trypsin level in the reported patient with perforated peptic ulcer. Increased serum trypsin was also found in 3 of 6 cases of acute cholecystitis and in one case of haemoperitoneum. It was found difficult to provide a reasonable explanation. However, minimal pancreatitis cannot be excluded. Although the pancreas seemed grossly normal at laparotomy, even the palpating surgeon may be frequently uncertain as to the normality of the pancreas (Levitt and Johnson, 1978).

The kidney seems to play a quantitatively important role in trypsin elimination (Elias et al., 1977; Borgstrom and Ohlsson, 1978). According to the 
present results and others (Elias et al., 1977) serum trypsin levels in chronic renal failure can be as high as those achieved in acute pancreatitis. Immunoreactive trypsin has been estimated in urine after concentrating it up to 25 times (Lake-Bakaar et al., 1979; Lake-Bakaar and Summerfield, 1978). Its urinary clearance is very low and it increases in pancreatic carcinoma and in about $67 \%$ of patients with acute pancreatitis (Lake-Bakaar et al., 1979). The mechanism is still unknown. It might be an interference in the tubular reabsorption and digestion of the filtered trypsin (Lake-Bakaar et al., 1979; Borgstrom, 1978).

Measurement of serum trypsin seems to be a specific test for the diagnosis of acute pancreatitis. Renal failure must always be excluded. Furthermore, it is suggested that serum trypsin should be prospectively measured in a larger series of acute nonpancreatic abdominal conditions, especially in those such as peptic ulcer perforation, which can clinically imitate acute pancreatitis (Banks, 1979), and not infrequently occurs together with high serum levels of amylase and even lipase (Banks, 1979; Salt II and Shenker, 1976).

\section{References}

Banks, P.A. (1979) Pancreatitis. 1st edn, p. 65. Plenum Medical Book Company, New York and London.

Borgstrom, A. \& Ohlsson, K. (1978) Studies on the turnover of endogenous cathodal trypsinogen in man. European Journal of Clinical Investigation, 8, 379.

Elias, E., Redshaw, M. \& Wood, T. (1977) Diagnostic importance of changes in circulating concentrations of immunoreactive trypsin. Lancet, ii, 66.

Lake-BakaAr, G., McKavanagh, S., Rubio, C.E., Epstein, O. \& Summerfield, J.A. (1980a) Measurement of trypsin in duodenal juice by radioimmunoassay. Gut, $21,402$.

Lake-BakaAR, G., McKavanagh, S. \& Summerfield, J.A. (1979) Urinary immunoreactive trypsin excretion: a noninvasive screening test for pancreatic cancer. Lancet, ii, 878.
Lake-BakaAr, G., McKavanagh, S., Wood, T., Redchaw?ִ M. \& Summerfield, J.A. (1978a) Assessment of the valu交 of changes in serum concentration of immunoreactiv $\mathbb{E}$ trypsin after a Lundh meal. Gut, 19, A446.

LaKe-BaKaAR, G., Rubio, C.E., MCKavanagh, $\mathrm{S}$ PotTer, B.J., \& SUmmerfield, J.A. (1980b) Metabolisn of ${ }^{125} \mathrm{I}$-labelled trypsin in man: evidence for recirculation Gut, 21, 580.

LaKe-BaKaAR, G., Rubio, C.E., McKavanagh, S. \& Summerfield, J.A. (1978b) Clearance of $I^{125}$ labelle $\bar{d}$ human trypsin from the serum: evidence for recirculatiora in man. Gut, 19, A960.

Lake-BakaAr, G., Smith-Laing, G. \& Summerfield, J.A (1978c) Origin of serum trypsin: evidence for intestinaL reabsorption. Gut, 19, A445.

LAKe-BAKAAR, G. \& Summerfield, J.A. (1978) Urinetrypsin concentration in the diagnosis of pancreatic. disease. Gut, 19, A445.

LevitT, M.B. \& Johnson, S.G. (1978) Is the Clam/Clcr value for the diagnosis of pancreatitis? Gastroenterology $75,118$.

Liebow, C.H. \& Rothman, S.S. (1975) Enteropancreatiơ circulation of digestive enzymes. Science, 189, 472.

Lifton, L.J., Slickers, K.A., Pragat, D.A. \& Katz, L.A (1974) Pancreatitis and lipase. A reevaluation with a fiveiu minute turbidimetric lipase determination. Journal of the American Medical Association, 229, 47.

NARDI, G.L. (1958) Serum trypsin determination in pan creatic disease. Journal of Laboratory and Clinical Invest - gation, 52, 66.

Salt II, W.B. \& Shenker, S. (1976) Amylase-its clinica․ significance: a review of the literature. Medicine. Baltimore 55, 269.

TEMLER, R.S. \& Felber, J.P. (1976) Radioimmunoassay human plasma trypsin. Biochimica et biophysica a\&a: 445, 720.

Warshaw, A.L. \& Lesser, P.B. (1975) Amylase/creatin clearance in differentiating acute pancreatitis from peptic ulcer with hyperamylasemia. Annals of Surgery, 181, 314

Webster, P.D. \& Zieve, L. (1962a) Alterations in serum? content of pancreatic enzymes. New England Journal of Medicine, 267, 604.

Webster, P.D. \& Z Zieve, L. (1962b) Alterations in serum content of pancreatic enzymes. New England Journal of Medicine, 267, 654.

Zimmons, D.S., Falkenstein, D.B., Riccobono, C. \&0 AARON, B. (1975) Complications of endoscopic retrograde cholangiopancreatography. Gastroenterology, 69, 303. 